\title{
Optimalisasi Geostrategi Indonesia di Selat Malaka
}

\author{
Frisky Amirul Haqiqi \\ Universitas Brawijaya
}

\begin{abstract}
The Strait of Malacca is the busiest in the world. It happens because the Malacca Strait is one of the essential keys in energy trading. It started from being the target of pirates and armed robbery to the target of foreign intervention in the Malacca Strait. Feeling that its sovereignty was threatened, Indonesia did several things to maintain the sovereignty of the Malacca Strait as part of Indonesian territory. It was starting from the refusal to cooperate with foreigners to cooperate with the littoral state. This paper will explain the importance of the Malacca Straits in world trade and why Indonesia's sovereignty is threatened due to foreign activities in the Malacca Strait. This paper is based on Indonesia's geostrategy and National Resilience which is part of Indonesia's geostrategy itself.
\end{abstract}

Keywords: Malacca Strait, Geostrategy, Sovereignty, Indonesia

\section{PENDAHULUAN}

Perairan laut merupakan salah satu hal yang terpenting dalam sejarah manusia sejak zaman dahulu. Bukan hanya menjadi sumber pangan dan keanekaragaman hayatinya yang dapat memenuhi kebutuhan hidup manusia saja, namun juga menjadi jalur perdagangan yang penting. Hal ini dapat terjadi karena $71 \%$ bagian bumi berupa laut, dan banyak negara yang dipisahkan oleh laut sehingga untuk melakukan perdagangan, laut menjadi salah satu hal yang penting. Bahkan $80 \%$ perdagangan dunia terjalin lewat perairan laut (Aldebaran, 2016).

Dalam menjalankan suatu perdagangan, pastinya akan memperhitungkan konsekuensi dalam melakukan perdagangan lewat laut, seperti lamanya perjalanan serta keamanan dari jalur tersebut. Salah satu cara yang dapat dilakukan untuk mempersingkat perjalanan adalah dengan melewati perairan selat. Selat dapat dikatakan sebagai sebuah fenomena geografi yang terjadi secara alami yang mengacu kepada jalur perairan yang sempit yang biasanya menghubungkan dua laut yang besar. Menurut International Court of Justice, selat adalah jalur perairan yang ada secara alami yang menghubungkan dua laut bebas dan biasanya digunakan sebagai jalur perdagangan internasional (Dastjerdi \& Nasrabady, 2020). Selat sendiri sudah digunakan dalam hal ekonomi maupun secara militer sejak dulu. Kontrol terhadap selat begitu penting dalam hal perekonomian dan militer dengan cara pemblokiran maupun pembukaan jalur selat, dan bahkan negara great powers pada Perang Dingin mempunyai strategi sendiri dalam penggunaan selat (Dastjerdi \& Nasrabady, 2020). Namun, semenjak berakhirnya Perang Dingin, selat lebih sering digunakan untuk kepentingan ekonomi yaitu sebagai jalur penting perdagangan internasional lewat perairan.

Selat ini merupakan salah satu sumber ketakutan bagi negara yang mempunyai kepentingan, khususnya dalam hal impor energi seperti minyak. Ketakutan mereka berada pada penutupan jalur perairan tersebut entah dengan cara paksa maupun lewat kekuatan militer. Di dunia ini ada beberapa selat yang menjadi jalur penting perdagangan energi dunia, yaitu : Selat Hormuz dalam perdagangan minyak dunia; Selat Dardanella dalam perdagangan minyak; Selat Bab el-Mandab dan Terusan Sues bagi perdagangan minyak di Timur Tengah; Selat Jabal Tariq untuk perdagangan komoditas di Eropa dan Afrika; Kanal Panama untuk perdagangan minyak serta perdagangan komoditas di Eropa dan Amerika; dan Selat Malaka

[corresponding author: friskyalhq@student.ub.ac.id] 
dalam perdagangan minyak dunia serta menjadi penghubung ke Samudera Pasifik (Dastjerdi \& Nasrabady, 2020).

Indonesia merupakan negara kepulauan terbesar yang mempunyai luas perairan laut hingga 6,3 juta $\mathrm{km}^{2}$ dan dengan jumlah pulau terbanyak hingga 17.504 serta garis pantai yang mencapai hampir $100.000 \mathrm{~km}$. Indonesia pun memiliki tempat yang strategi dimana letak Indonesia berada pada pertengahan antara benua Asia dan Australia serta terletak di pertemuan antara samudera Pasifik dan samudera Hindia (Fathun, 2019). Hal ini membuat posisi Indonesia menjadi strategis, ditambah lagi Indonesia mempunyai salah satu selat penting dalam perdagangan minyak dunia, yaitu Selat Malaka. Berkat posisi yang strategis ditambah dengan adanya Selat Malaka, membuat Indonesia menjadi salah satu negara penting yang harus diperhatikan kala melakukan perdagangan internasional khususnya di bidang minyak. Hal ini berhasil membuat banyak pihak tertarik untuk mengambil keuntungan dengan cara legal maupun ilegal.

Cara yang legal disini adalah dengan cara mengajak Indonesia untuk bekerjasama dibidang ekonomi maupun keamanan dalam hal Selat Malaka, namun masing - masing pihak mempunyai kepentingan tersendiri. Sedangkan cara ilegal dengan seperti melakukan illegal fishing (jangan lupa bahwa Selat Malaka mempunyai keanekaragaman hayati yang dapat memenuhi kebutuhan pangan) hingga tindakan pembajakan kapal yang dijadikan media transportasi maupun kapal dagang yang digunakan untuk kegiatan ekspor impor barang.

Dari penjelasan diatas, Indonesia merasa bahwa kedaulatannya terancam dengan adanya campur tangan pihak lain, entah itu dari pihak negara yang berkepentingan di Selat Malaka maupun dari ancaman perompakan. Maka dari itu, Indonesia berusaha untuk melakukan usaha apapun yang sekiranya dapat menjaga kedaulatan Indonesia dari pihak lain. Mulai dari menjalin kerjasama dengan Malaysia dan Singapura sebagai negara yang sama sama berada di tepi Selat Malaka, penolakan ajakan kerjasama dari negara lain, serta usaha militer dalam mengatasi aksi perompak di selat ini.

Dalam tulisan ini akan menjelaskan Geostrategi Indonesia serta konsep Ketahanan Nasional. Konsep ini digunakan untuk menjelaskan alasan mengapa Indonesia melakukan beberapa hal yang akan dijelaskan di tulisan ini. Selanjutnya menjelaskan tentang profil singkat dari Selat Malaka dan pentingnya selat tersebut dalam perdagangan dunia, serta pembahasan tentang beberapa pihak yang mempunyai kepentingan. Dilanjutkan dengan pembahasan tentang alasan Indonesia menganggap bahwa aksi yang dilakukan oleh pihak tersebut mengancam kedaulatan Indonesia.

\section{KERANGKA PEMIKIRAN}

\section{Geostrategi Indonesia}

Pada dasarnya geostrategi mempunyai definisi sebagai kemana arah geografis dari kebijakan luar negeri suatu negara. Lebih tepatnya, geostrategi memperlihatkan kemana negara memfokuskan militer powerprojection nya serta berbagai usaha diplomatik. Perlu diingat bahwa sumber daya yang dimiliki oleh negara adalah terbatas, sehingga penggunaan sumber daya ini harus hati - hati dan difokuskan kepada sektor yang memang krusial. Variabel utama dari geostrategi adalah batas negara, negara akan melakukan apapun untuk melindungi teritorinya dari serangan dan invasi dan batas negara adalah salah satu alat ukur yang tepat untuk keamanan teritori (Grygiel, 2006). Biasanya, fokus negara dalam melindungi teritorinya berada pada daratan dibandingkan dengan lautan. Namun, hal ini sebenarnya tergantung dari letak geografis negara itu sendiri. Lagipula negara dengan batas daratan seringkali berada dalam kondisi stabil, jika negara tetangganya mempunyai hubungan yang baik (Grygiel, 2006). Kesimpulannya, batas negara begitu mempengaruhi arah dari geostrategi suatu negara. Jika 
batas negara terprovokasi, maka negara akan mengeluarkan segala usahanya dalam hal ini dan membatasi usaha kendali dari sumber daya dan rute perdagangan.

Indonesia sebagai negara kepulauan, tak dapat dipungkiri bahwa dalam hal keamanan batas negara akan susah untuk mengontrol semua wilayah. Karena hal ini, Indonesia pada awal kemerdekaan mengalami banyak permasalahan keamanan khususnya di daerah maritim Indonesia. Seperti adanya penyelundupan, pemberontak yang kian bertambah, dan adanya kecurigaan aktivitas maritim asing dengan hasrat yang buruk berkeliaran di laut Indonesia. Maka dari itu, Perdana Menteri Indonesia Djuanda Kartawidjaja mengeluarkan sebuah deklarasi yang dikenal sebagai Deklarasi Djuanda 1957. Deklarasi ini berisikan tentang pendeklarasian bahwa semua perairan yang ada di sekeliling, diantara, dan yang menghubungkan berbagai pulau milik Indonesia, berada pada teritori Indonesia, sehingga menjadi bagian dari perairan nasional Indonesia dan secara eksklusif dibawah kedaulatan Indonesia (Laksmana, 2011). Hal ini dibantu dengan adanya perjanjian dibawah UNCLOS ${ }^{1}$. Pada tahun 1982, UNCLOS mengeluarkan sebuah peraturan yang salah satunya adalah kepemilikan laut 12 nautical miles dari garis pantai (Kusuma, 2013).

Dalam merumuskan sebuah geostrategi, perlunya perhitungan terhadap kondisi serta kondisi geografi suatu negara. Perumusan geostrategi Indonesia bukanlah dengan tujuan untuk melakukan ekspansi diluar wilayah kedaulatan Indonesia, melainkan lebih kepada cara atau metode yang digunakan untuk mengembangkan potensi sumber daya Indonesia dengan tujuan pengamanan kedaulatan negara Indonesia (Mulyono, 2017).

Di Indonesia, geostrategi didefinisikan sebagai sebuah cara yang digunakan untuk menentukan arah kebijakan serta arah penggunaan sarana dengan tujuan untuk mencapai tujuan bangsa dengan asas kemanusiaan dan keadilan sosial (Agus, 2015). Tujuan dari geostrategi Indonesia sendiri diarahkan kepada lima hal, yaitu : penegakan hukum dan ketertiban; perwujudan kesejahteraan dan kemakmuran; pertahanan dan keamanan; keadilan hukum dan sosial; serta kebebasan rakyat (Agus, 2015). Dalam pelaksanaannya, geostrategi Indonesia berusaha untuk diwujudkan lewat adanya konsep Ketahanan Nasional.

\section{Ketahanan Nasional}

Ketahanan Nasional dapat didefinisikan sebagai suatu kondisi bangsa yang dinamis yang selalu dalam mempertahankan kedaulatannya dihadapkan oleh berbagai ancaman dan hal ini diupayakan dengan melalui pembangunan nasional di seluruh aspek kehidupan nasional (Suradinata, 2001). Aspek kehidupan nasional ini berdimensi Asta Gatra. Asta Gatra sendiri merupakan sebuah kehidupan nasional yang kompleks namun disederha-nakan sedemikian rupa, tapi tetap mencerminkan kehidupan nasional yang nyata (Suradinata, 2001). Asta Gatra terdiri dari dua aspek, yaitu tiga unsur yang terkandung dalam aspek ilmiah (Tri Gatra) dan aspek sosial yang berjumlah lima unsur (Panca Gatra) (Agus, 2015). Ketika dua aspek ini dijumlah maka berjumlah delapan unsur sehingga dinamakan Asta Gatra. Aspek ilmiah yang berjumlah tiga, terdiri dari geografi, demografi, dan sumber kekayaan alam. Sedangkan aspek sosial yang berisi lima unsur terdiri dari, ideologi, ekonomi, politik, sosial budaya, dan pertahanan dan keamanan (Mulyono, 2017). Keterkaitannya dengan geostrategi adalah, geostrategi dalam pelaksanaannya tergantung kepada pemberdayaan aspek ilmiah atau Tri Gatra yang ditujukan untuk meningkatkan ketahanan aspek sosial atau Panca Gatra.

\footnotetext{
${ }^{1}$ United Nation Convention on the Law of the Sea
} 


\section{KERANGKA PEMIKIRAN}

\section{Arti Penting Selat Malaka}

Selat Malaka merupakan selat yang berada diantara Semenanjung Malaya dan Pulau Sumatera dengan panjang $800 \mathrm{~km}$ dengan lebar $65 \mathrm{~km}$ dan sedalam 22.5m (Fathun, 2019). Selat Malaka adalah jalur yang paling cepat dan tersingkat yang menghubungkan antara Asia dan India.Selat Malaka ini menjadi salah satu "choke point" perdagangan dunia yang menghubungkan Laut Cina dengan Samudera Hindia, dan dengan lebar tersempit hanya selebar $2.8 \mathrm{~km}$ saja, menjadikan Selat Malaka sebagai salah satu selat dengan tingkat kemacetan yang signifikan di dunia (Evers \& Gerke, 2011). Selat Malaka ini telah menjadi jalur distribusi barang dan energi dunia yang dibuktikan dengan jumlah kapal yang melintas di selat ini lebih dari 70.000 kapal, dan seringkali yang melintas adalah kapal berjenis kontainer maupun tanker dari Timur Tengah menuju Laut Cina Selatan maupun sebaliknya (Aldebaran, 2016). Seperempat perdagangan dunia pasti melewati jalur ini dengan membawa minyak serta gas alam cair sejumlah 525 juta ton yang memiliki nilai setara dengan $\$ 390$ miliar dolar AS setiap tahunnya (Massey, 2008). Dari sekian banyaknya jalur perdagangan lewat laut, Selat Malaka merupakan salah satu jalur perniagaan yang ramai dan padat hingga menjadi selat tersibuk di dunia (Panduwinata, 2016).

Selat Malaka bagi negara littoral states (Indonesia, Malaysia, dan Singapura) mempunyai nilai penting tersendiri. Terlepas dari menjadi jalur perdagangan tersibuk di dunia, Selat Malaka juga menjadi salah satu sumber pangan penting bagi Indonesia dan Malaysia. Bagi Indonesia, Selat Malaka merupakan sumber penangkapan ikan terbesar kedua setelah Laut Jawa dan sedangkan bagi Malaysia dapat menghasilkan sebesar $60 \%$ dari total penangkapan ikan selama satu tahun (Kawengian, 2017).

Selat Malaka "dimiliki” oleh beberapa negara sekaligus, hal ini terjadi karena adanya perjanjian UNCLOS ketiga yang berisi tentang penambahan 12 mil dari garis pantai menjadi bagian dari kedaulatan sebuah negara. Sebelum adanya perjanjian UNCLOS ketiga, seperti yang sudah dijelaskan diatas bahwa Indonesia sudah mengklaim bahwa perairan disekitar Indonesia sepanjang 12 mil dari garis pantai. Hal ini sempat membuat hubungan Indonesia dan Malaysia renggang, karena Malaysia pun juga berbuat hal yang sama demi menyesuaikan kebijakan Indonesia (Matthews, 2015). Untuk menghindari konflik yang tidak diperlukan, Jakarta mengundang Kuala Lumpur untuk mendiskusikan hal ini. Akhirnya kedua belah pihak merasa mendapatkan kepuasan setelah berdiskusi dan membuat perjanjian terkait hal ini dengan cara membuat batas negara dibagian tengah atau median dari titik terluar di masing - masing sisi pulau pada tahun 1970 di Kuala Lumpur (Matthews, 2015).

Bagi negara - negara dan pihak yang berkepentingan dan rajin melewati selat ini, maka sudah hal yang logis jika mereka menginginkan Selat Malaka ini menjadi perairan internasional yang bebas tanpa ada yang mengklaim perairan tersebut. Akan tetapi, yang dilakukan oleh littoral states khususnya Indonesia dan Malaysia adalah sebaliknya. Kedua negara ini dengan terang - terangan mendeklarasikan bahwa Selat Malaka bukanlah perairan bebas internasional, melainkan bagian dari wilayah kedaulatan masing - masing negara. Deklarasi ini dikeluarkan pada 16 November 1971, dan walaupun Singapura tidak mendukung secara penuh deklarasi ini, namun ketiga negara ini sepakat akan tiga hal, yaitu (Matthews, 2015):

- Keselamatan navigasi di Selat Malaka merupakan kewajiban dari ketiga littoral states dan membutuhkan kerjasama antar ketiga negara.

- Untuk mencapai sebuah kerjasama sepenuhnya, akan dibuat sebuah badan kerjasama yang beranggotakan tiga negara berkaitan saja.

- Keselamatan navigasi dan internasionalisasi selat dianggap sebagai dua isu yang terpisah dan berbeda. 
Berdasarkan perjanjian UNCLOS ketiga, memang tertulis bahwa ada penambahan 12 mil dari garis pantai untuk menjadi wilayah kedaulatan negara. Namun pada pasal 43 UNCLOS tertulis bahwa user states atau negara pengguna perairan tersebut memiliki kewajiban untuk burden sharing dengan littoral states dalam hal keamanan pesisir, keselamatan navigasi, serta membantu menjaga kelestarian keanekaragaman hayati di tempat tersebut (Kusuma, 2013). Dengan alasan ini, banyak pihak yang ingin membentuk kerjasama terkait dengan Selat Malaka dengan maksud tertentu (hal ini akan dibahas lebih lanjut dibawah).

Selat Malaka yang menjadi salah satu selat terpenting dalam dunia perniagaan membuat banyak pihak berkepentingan berusaha untuk mengambil keuntungan dari selat ini entah itu dari cara legal maupun ilegal.

Tak dapat dipungkiri bahwa Selat Malaka sebagai selat tersibuk di dunia tentunya akan memancing perompak untuk datang dan membajak kapal demi mendapatkan keuntungan. Dari tahun 1994, jumlah total penyerangan bajak laut terhadap kapal yang melintasi Selat Malaka ini sebanyak 25 kali percobaan, dan hanya dalam kurun 6 tahun jumlah penyerangan mencapai 200 pada tahun 2000 (Evers \& Gerke, 2011). Selat Malaka juga dianggap sebagai selat yang paling rawan menjadi sasaran perompak di dunia pada tahun 2000 (Aldebaran, 2016). Selat Malaka juga pada saat itu mendapatkan separuh dari seluruh total kegiatan perompakan di seluruh dunia (Massey, 2008). Dengan demikian dapat disimpulkan bahwa Selat Malaka sempat menjadi salah satu jalur perdagangan yang berbahaya pada akhir tahun 1990an hingga awal tahun 2000an.

Selain menarik para perompak untuk datang ke Selat Malaka, jalur perdagangan ini juga menarik beberapa negara lain yang kehidupan ekonominya dapat dikatakan bergantung kepada selat ini. Beberapa negara ini berusaha untuk menjalin kerjasama dengan littoral states guna memastikan bahwa kepentingan mereka di jalur perdagangan ini terpenuhi. Diantaranya adalah (Matthews, 2015):

a. Jepang

Jepang merasa cemas dengan adanya klaim dari Indonesia dan Malaysia atas Selat Malaka. Selat Malaka bagi Jepang adalah sumber utama pasokan energi untuk Jepang. Bahkan 90\% minyak yang diimpor dari Timur Tengah sudah pasti melalui selat ini untuk menuju Jepang. Jepang khawatir bahwa littoral states tidak mempunyai kapabilitas yang memadai untuk menjaga keselamatan navigasi di selat tersebut. Sehingga, Jepang ingin untuk menjadikan selat tersebut menjadi perairan internasional lagi. Namun, sadar bahwa hal itu tak akan terjadi setelah adanya deklarasi oleh Indonesia dan Malaysia, Jepang pun berusaha untuk menjalin kerjasama dengan kedua littoral states tersebut dalam hal keamanan perairan dari ancaman perompak. Kerjasama ini diberi nama Regional Cooperation Agreement on Combating Piracy and Armed Robbery Against Ships (ReCAAP) pada tahun 2001. Setelah berbagai pertemuan, akhirnya pada tahun 2005 kerjasama ini dilaksanakan pada tahun 2005. Namun, Indonesia disini hanya ikut sebagai salah satu anggota negara yang menyusun kerjasama multilateral. Pada saat kerjasama ini dilaksanakan, Indonesia tidak meratifikasi sekaligus tidak menandatangani kerjasama ini.

b. Amerika Serikat

Respon Amerika Serikat hampir sama dengan Jepang, yaitu menuntut kebebasan dalam hal pelayaran lewat jalur Selat Malaka ini. Namun, berbeda dengan Jepang, Amerika Serikat sanggup untuk menerima kenyataan bahwa Selat Malaka sudah diklaim oleh Indonesia serta Malaysia dan mengakui bahwa jarak 12 mil dari garis pantai masih masuk kedalam wilayah kedaulatan kedua negara tersebut. Namun, Amerika Serikat menyatakan bahwa mereka sanggup menerima jarak 12 mil tersebut dengan syarat littoral states tetap memberikan hak kebebasan transit di selat tersebut untuk penggunaan internasional. 
Terlepas dari penerimaan Amerika Serikat terhadap implementasi peraturan 12 mil di Selat Malaka, Amerika Serikat terus berusaha untuk mendapatkan akses informasi secara langsung dari sumbernya di Selat Malaka ini. salah satu caranya adalah dengan membuat sebuah kerjasama maritim di kawasan Asia Tenggara yang dinamakan dengan Regional Maritime Security Initiative. Tujuan utama dari kerjasama regional ini adalah untuk menjaga keamanan maritim khususnya dari ancaman transnasional di kawasan Asia Tenggara pada khususnya. Ide dasar dari inisiatif ini adalah untuk menyediakan sebuah pasukan keamanan khusus di selat ini yang siap siaga untuk beraksi jika ada insiden ancaman maritim. Permasalahannya adalah, jika kerjasama ini disetujui oleh Indonesia dan negara lainnya, pasukan militer siapa yang akan digunakan disini? Apakah dari Amerika saja, atau negara kawasan Asia Tenggara saja, atau gabungan dari keduanya? Lalu siapa yang memberikan perintah dalam hal pelaksanaan jika ada insiden yang terjadi? Terlepas dari pertanyaan tersebut, Indonesia pun menolak ajakan dari Amerika Serikat.

c. Singapura

Singapura adalah satu - satunya littoral state yang menolak adanya klaim teritori di Selat Malaka. Walaupun Singapura merupakan bagian dari deklarasi 1971 dengan Indonesia dan Malaysia, Singapura mendukung akan adanya kebebasan navigasi di selat ini. Singapura merasa bahwa adanya deklarasi tersebut merupakan usaha dari Indonesia dan Malaysia dalam melemahkan ekonomi Singapura dengan dalih mempromosikan kontrol lingkungan.

Dari ketiga negara tersebut, Indonesia menganggap bahwa Amerika Serikat dan Jepang mempunyai maksud tertentu ketika melakukan ajakan untuk membentuk sebuah kerjasama di Selat Malaka ini. Indonesia menganggap bahwa ajakan kerjasama tersebut dapat mengancam kedaulatan Indonesia secara tidak langsung. Contohnya adalah RMSI milik Amerika Serikat yang mengusulkan tentang adanya pasukan yang bersiaga di selat, hal ini dapat mengancam kedaulatan jika pasukan yang disiagakan murni dari Amerika Serikat. Ditambah lagi dengan adanya kemungkinan akan adanya penggeledahan kapal oleh Amerika Serikat dengan dalih untuk keamanan dari ancaman teroris juga menjadi permasalahan bagi Indonesia.

\section{Usaha Indonesia dalam Menjaga Kedaulatan}

Seperti yang dijelaskan pada segmen sebelumnya bahwa Indonesia menolak ajakan kerjasama dengan kedua negara, yaitu Amerika Serikat dengan RMSI dan Jepang lewat ReCAAP nya dengan alasan kedaulatan. Untuk RMSI, Indonesia selain beralasan yang sudah dijelaskan diatas, Indonesia juga berargumen bahwa kemanan Selat Malaka merupakan kewajiban dari littoral states. Sehingga kapal asing tidak boleh mengintervensi akan hal ini karena akan menciderai kedaulatan dari littoral state itu sendiri (Matthews, 2015). Sedangkan untuk penolakan ratifikasi dan penandatanganan ReCAAP inisiasi Jepang adalah Indonesia sudah memiliki kerjasama tersendiri dalam hal ini, sehingga ReCAAP dirasa tidak begitu diperlukan, dan ReCAAP menurut Indonesia juga dapat mengikis kedaulatan yang dimiliki (Matthews, 2015).

Ketika Indonesia menolak ajakan kerjasama dari kedua negara tersebut, bukan berarti Indonesia akan berusaha sendirian untuk menjaga Selat Malaka dari ancaman luar dan menjaga kedaulatannya. Indonesia sudah mengantongi kerjasama terkait dengan adanya ancaman perompak di Selat Malaka ini.

Yang pertama adalah adanya kerjasama antara Indonesia, Malaysia dan Singapura yang dinamakan dengan MALSINDO. Kerjasama ini lebih kepada kerjasama dibidang patroli di Selat Malaka. Kerjasama ini diadakan untuk merespon kejahatan perampokan bersenjata di Selat Malaka yang kian meningkat jumlahnya. Kerjasama ini lebih ditekankan dengan adanya patroli bersama antar negara (Wijaya, 2017). Kerjasama MALSINDO, memang dalam 
pelaksanaannya masih tergolong ketat dalam artian berusaha untuk menghindari hal - hal yang dapat menimbulkan masalah kedaulatan, seperti pasukan militer dilarang untuk memasuki kawasan negara lain walaupun tengah mengejar musuh, antisipasi akan hal ini maka negara tersebut berkoordinasi dengan negara yang dituju oleh musuh (Gilmartin, 2008).

MALSINDO mempunyai dua produk yang berada di bawah MALSINDO sebagai upaya untuk mengamankan Selat Malaka dari ancaman luar. Kedua produk ini adalah Eyes in the Sky atau EIS dan Malacca Strait Sea Patrol (MSSP). MSSP sendiri diluncurkan oleh ketiga negara pada tahun 2004 dan kerjasamanya berfokus kepada patroli bersama dan saling keterbukaan dalam hal informasi yang didapat antar negara (Panduwinata, 2016). Kerjasama MSSP ini dapat dikatakan berhasil karena setelah diadakannya MSSP, tingkat perompakan di Selat Malaka menurun drastis jumlahnya, walaupun pada tahun 2011 hingga 2013 sempat meningkat (Panduwinata, 2016).

Program Eye in the Sky (EIS), merupakan program gabungan antara laut dan udara yang dilakukan oleh MALSINDO. Kerjasama ini dilaksanakan pada tahun 2005 memanfaatkan teknologi pesawat dan sejenisnya untuk melakukan patroli udara di sekitar Selat Malaka (Wijaya, 2017). EIS hanyalah untuk masalah pengawasan saja, artinya teknologi yang digunakan hanya ditujukan untuk patroli dan pengawasan Selat Malaka dan bukan untuk mengejar target atau ancaman (Gilmartin, 2008).

\section{KESIMPULAN}

Geostrategi Indonesia mempunyai tujuan bukan untuk ekspansi wilayah, melainkan untuk menjaga kedaulatan wilayahnya sendiri. Selat Malaka merupakan selat tersibuk di dunia dan seringkali menarik perhatian pihak yang ingin mendapatkan keuntungan dan hal ini dapat mengancam kedaulatan Indonesia. Maka dari itu, geostrategi Indonesia kali ini difokuskan kepada Selat Malaka guna menjaga kedaulatan Selat Malaka sebagai bagian dari wilayah Indonesia dari ancaman perampokan bersenjata maupun intervensi asing.

Dalam melindungi kedaulatan, Indonesia melakukan beberapa hal. Yang pertama adalah pencegahan adanya intervensi asing di daerah Selat Malaka. Dalam hal ini Indonesia menolak ajakan kerjasama Jepang (ReCAAP) dengan tidak meratifikasi dan menandatangani kerjasama tersebut dan juga RSMI milik Amerika Serikat untuk menghindari intervensi kedua negara tersebut dalam Selat Malaka.

Sedangkan usaha Indonesia untuk mengatasi permaslahan perompak dan perampokan bersenjata di wilayah Selat Malaka adalah, Indonesia menjalin kerjasama dengan littoral state di selat tersebut yaitu Malaysia dan Singapura. Kerjasama ini dinamakan MALSINDO. MALSINDO sendiri mempunyai dua produk yang ditujukan untuk fokus dalam patroli di Selat Malaka, yaitu MSSP dan Eye in the Sky. MSSP lebih berfokus kepada patroli menggunakan kapal kecil, sedangkan Eye in the Sky adalah penggunaan teknologi untuk melakukan pengawasan lewat udara atau air surveillance.

Semua hal yang dilakukan Indonesia di daerah Selat Malaka ini bukanlah semata mata menunjukkan kesombongan bahwa Indonesia dapat mengatasi permasahan tanpa adanya intervensi asing. Namun lebih kepada upaya Indonesia untuk menjaga kedaulatan wilayahnya yang dapat terkikis jika ada intervensi asing yang masuk dan ikut campur dalam permasalahan Selat Malaka.

\section{DAFTAR PUSTAKA}

Agus, A. A. (2015). URGENSI KETAHANAN NASIONAL SEBAGAI GEOSTRATEGI INDONESIA. Jurnal Integrasi, 1(2), 247-257.

Aldebaran, S. A. (2016). UPAYA LITTORAL STATES (INDONESIA, MALAYSIA 
DAN SINGAPURA) DENGAN USER STATES DALAM MEMBERANTAS KEJAHATAN ARMED ROBBERY (PEROMPAKAN BERSENJATA) DI SELAT MALAKA TAHUN 2008-2013. Journal of International Relations, 2, 72-79. http://ejournal-s1.undip.ac.id/index.php/jihi

Dastjerdi, H. K., \& Nasrabady, N. H. (2020). Role of malacca strait with a geopolitical and strategic approach. Geopolitics Quarterly, 16(4), 264-287.

Evers, H.-D. E., \& Gerke, S. (2011). The Strategic Importance of the Straits of Malacca. SSRN Electronic Journal, January. https://doi.org/10.2139/ssrn.1020877

Fathun, L. M. (2019). ASEAN Contemporary Security: Maritime Diplomacy in Handling of Maritime Security Threats in Malaka Strait. Insignia: Journal of International Relations, 6(1), 50. https://doi.org/10.20884/1.ins.2019.6.1.1414

Gilmartin, H. (2008). EU-U.S.-China: Cooperation in the Malacca Straits.

Grygiel, J. J. (2006). Great powers and geopolitical change. Great Powers and Geopolitical Change, 60(2), 1-258. https://doi.org/10.1080/00330120701787241

Kawengian, A. D. M. (2017). Penolakan Indonesia Terhadap Kerjasama Keamanan Selat Malaka Terkait "Proliferation Security Initiative" dengan Amerika Serikat. Jurnal Analisis Hubungan Internasional, 6(2). http://www.southasianalysis.org/paper1033

Kusuma, A. S. (2013). Securing Indonesia's Sovereignty in the Sea: Focusing on Security Management in Malacca Strait Securing Indonesia's Sovereignty in the Sea : Focusing on Security Management in Malacca Strait.

Laksmana, E. A. (2011). The enduring strategic trinity: explaining Indonesia's geopolitical architecture. Journal of the Indian Ocean Region, 7(1), 95-116. https://doi.org/10.1080/19480881.2011.587333

Massey, A. S. (2008). Maritime security cooperation in the Strait of Malacca [Naval Postgraduate School]. http:/ /oai.dtic.mil/oai/oai?verb=getRecord\&metadataPrefix $=$ html\&identifier $=$ AD A483524

Matthews, A. (2015). Indonesian Maritime Security Cooperation in the Malacca Straits. Naval Postgraduate School.

Mulyono, H. (2017). Geostrategi Indonesia dalam Dinamika Politik Global dan Regional. Jurnal Kajian Lembannas RI, 29, 19.

Panduwinata, Y. (2016). Pengawasan Wilayah Laut Selat Malaka Pada Kerjasama Malacca Strait Sea Patrols Tahun 2011 - 2013: Perspektif Indonesia. Journal of International Relations, 2(4), 276-281.

Suradinata, E. (2001). Geopolitik Dan Geostrategi Dalam Mewujudkan Integritas Negara Kesatuan Republik Indonesia. Jurnal Ketahanan Nasional, 6(2). https://doi.org/10.22146/jkn.22056

Wijaya, S. M. I. (2017). Usaha Malsindo Trilateral Coordinated Patrol dalam Menangani Perampokan Bersenjata di Selat Malaka. Journal of International Relations, 3(4), 189195. 